\title{
PENGGUNAAN OJEK SYARIAH SEBAGAI MODA TRANSPORTASI MUSLIMAH URBAN: MEREK ATAU RELIGIUSITAS?
}

\author{
Aniesa Samira Bafadhal \\ Program Studi Pariwisata, Universitas Brawijaya \\ Email: aniesa.bafadhal@ub.ac.id
}

\begin{abstract}
The increasing need for travel in the local area of the house (staycation) such as shopping, culinary, health and education tours have encouraged the use of various modes of public transportation in urban communities. In the midst of these conditions, Muslimah's need for public transportation that meets the principles of sharia values and is safe from harassment and urban crime, OJESY is here as the first and only sharia motorcycle taxi for women in Indonesia. This study analyzes whether Muslimah consumers choose to use OJESY services because of the sharia brand offered by OJESY or because of consumer religiosity. The respondents of this study were 116 Muslim women using OJESY in Malang City, East Java. By using multiple regression the results of this study indicate that both the brand of sharia and religiosity show a significant and positive influence on customer decisions to use Islamic motorcycle taxi services, but religiosity is the main stimulus so spiritual-driven plays an important role in Muslimah decisions to use public transportation while maintaining the Islamic values it adheres to.
\end{abstract}

\section{Keywords: Sharing Economic, Halal Transportation, Online Motorcycle Taxi, Sharia Brand, Religiosity}

\begin{abstract}
ABSTRAK
Semakin meningkatnya kebutuhan berwisata area lokal rumah (staycation) seperti wisata belanja, kuliner, kesehatan dan edukasi telah mendorong penggunakan berbagai moda transportasi public pada masyarakat urban. Ditengah kondisi tersebut, untuk menjawab tuntutan Muslimah atas transportasi publik yang memenuhi prinsip nilai-nilai syariah sekaligus cenderung aman dari pelecehan dan kriminalitas perkotaan, OJESY hadir sebagai ojek syariah khusus perempuan pertama dan satu-satunya di Indonesia. Penelitian ini menganalisis apakah konsumen Muslimah memilih untuk menggunakan jasa OJESY karena merek syariah yang ditawarkan dari OJESY atau karena religiusitas konsumen semata. Responden penelitian ini adalah sebanyak 116 orang Muslimah pengguna aplikasi OJESY dan memanfaatkan moda transportasi tersebut di Kota Malang, Jawa Timur. Dengan menggunakan regresi berganda hasil penelitian ini menunjukkan bahwa baik merek syariah maupun religiusitas menunjukkan pengaruh signifikan dan positif terhadap keputusan pelanggan menggunakan jasa ojek syariah, namun religiusitas merupakan stimulus utama sehingga spiritual-driven memainkan peran penting dalam keputusan Muslimah menggunakan moda transportasi umum sekaligus menjaga nilai-nilai syariah yang dianutnya.
\end{abstract}

\section{Kata Kunci: Sharing Economic, Transportasi Halal, Ojek Daring, Merek Syariah, Religiusitas}




\section{PENDAHULUAN}

Motif spiritual dalam agama telah lama menjadi bagian yang tidak terpisahkan dari kegiatan perjalanan. Dalam sepanjang sejarah Islam, "perjalanan" (yang dapat diartikan dengan istilah travelling) telah memiliki kaitan erat dengan meningkatnya spiritualitas Muslim. Di tengah kompleksnya definisi mengenai istilah pariwisata, Duman (2011) menyajikan definisi pariwisata yang sesuai syariat Islam sebagai "kegiatan umat Islam bepergian dan tinggal ke tempat-tempat di luar lingkungan mereka untuk tidak lebih dari satu tahun berturut-turut dan partisipasi kegiatan mereka berasal dari motivasi Islam serta tidak berkaitan dengan pelaksanaan kegiatan yang dibayar dari dalam tempat yang dikunjungi ".

Sebelumnya, banyak orang percaya bahwa produk halal hanya terkait tuntunan konsumsi makanan dan minuman yang sesuai syariat Islam, tetapi dengan kuatnya dorongan asimilasi kebutuhan agama ke dalam gaya hidup, produk halal juga menjadi semakin beragam, tidak terkecuali transportasi halal. Pendapat senada dikemukakan Akyol and Kilinc (2014) dimana sebagai ceruk pasar, pariwisata Islam yang halal meliputi sektor-sektor yang saling terkait seperti hotel halal, restoran makanan halal, paket wisata halal, salon dan spa syariah dan keuangan syariah dan bahkan transportasi halal.

Pengertian sistem atau moda transportasi secara umum adalah sistem untuk memindahkan orang atau barang dimana moda angkutan umum adalah sistem angkutan umum di lingkungan perkotaan (Garrison and Livenson, 2006). Salah satunya melalui kehadiran ojek online di Indonesia.Ojek telah mendapat respon baik dari masyarakat, pasalnya ojek online dapat memudahkan para penggunanya memesan ojek dimanapun dan kapanpun tanpa bersusah payah mencari tukang ojek disekitarnya. pengguna cukup membuka aplikasi lalu memesannya, maka tidak lama rider pun akan datang menjemput penumpang dilokasi mereka berada. Dalam penerapan moda transportasi secara daring tersebut, muncul tren penerapan model sharing economic dalam operasional bisnis perusahaan yang didukung oleh peningkatan teknologi dan internet. Sharing economic adalah sebuah bisnis dengan konsep ekonomi berbagi dalam hal sumber daya baik manusia maupun modal, termasuk ide, produksi, distribusi, perdagangan dan konsumsi barang dan jasa oleh orang-orang atau organisasi yang berbeda-beda.
Penerapan transportasi sesuai nilai-nilai syariah merupakan konsep utama transportasi halal.Namun apakah konsep sharing economic sudah sesuai dengan prinsip syariah?. Dalam prinsip syariah, akad yang digunakan untuk usaha harus jelas, agar dapat menentukan siapa yang harus menanggung biaya. Jika akad yang digunakan adalah akad kerjasama (syirkah), maka biaya-biaya yang secara tidak langsung ditanggung oleh rider sebagai pemilik motor seharusnya diakui dalam bentuk jumlah investasi rider yang nantinya mempengaruhi jumlah bagi hasil akan yang dibagikan, baik keuntungan maupun kerugian. Jika akad yang digunakan adalah sewa (ijarah), maka biaya-biaya yang secara tidak langsung ditanggung oleh rider sebagai pemilik mobil seharusnya diakui dalam bentuk biaya penyewaan mobil oleh perusahaan dan dibayarkan kepada rider di luar komisi atau upah sebagai pengemudi.

Selain itu, hampir semua jasa ojek dijalankan oleh laki-laki, sehingga ini menimbulkan masalah baru bagi Muslimah yang ingin menggunakan jasa ojek namun tidak mau naik motor selain dengan keluarga dan sesama jenis kelamin (muhrim), disisi lain juga sering terdengarnya berita-berita pelecehan seksual terhadapat kaum hawa diangkutan umum. Idelanya secara umum, dalam hal operasional ojek syariah harus dilakukan pemisahan rider berdasarkan jenis kelamin konsumen serta dalam pelayanan ojek syariah tidak diperbolehkan melayani pengantaran makanan, bahan atau material lainnya yang mengandung unsur non-halal seperti makanan yang mengandung babi. Lebih lanjut, diharapkan rider ojek syariah berpakaian yang menutup aurat, aman dan sederhana.

Menjawab tantangan tersebut, Ojek Syari Indonesia (OJESY) didirikan pada tanggal 10 Maret 2015 dengan nama PT. OJEK SYARI INDONESIA mengklaim sebagai ojek pertama khusus untuk wanita Indonesia. Dengan terus mengembangkan layanan pada 19 kota di Indonesia yaitu Surabaya, Sidoarjo, Malang, Gresik, Madiun, Solo, Semarang, Yogyakarta, Bandung, Bogor, Bekasi, Depok, Tangerang, Tangerang Selatan, Jakarta Barat, Jakarta Selatan, Jakarta Timur, Jakarta Utara, Jakarta Pusat, Makassar, Purbalingga, Purwokerto, Banjarnegara, Bojonegoro, Cilacap.

PT. Ojek Syari Indonesia (OJESY) menggunakan metode pemesanan secara daring dengan aplikasi khusus bernama OJESY yang harus diunduh dari playstore seperti yang 
ditampilkan pada gambar 1. OJESY menerapkan sistem sharing economic dengan pengemudi yang terdaftar dalam OJES. Pengemudi atau rider dalam OJESY disebut Sahabat Pengendara. OJESY sangat selektif dan menekankan syaratsyarat formal maupun syariah yang ketat untuk menjadi Sahabat Pengendara antara lain 1) Muslimah berjilbab dan berpakaian longgar, 2) Mempunyai SIM C, 3) Mempunyai kendaaran motor dengan kondisi keamanan motor dan surat yang lengkap, 4) Bisa berkendara dengan baik dan aman, 5) Mempunyai smartphone android minimal versi 4.2 dan mampu mengoperasionalkan chat whatsapp, 6) Mendapatkan ijin bergabung oleh suami/ayah/ibu/saudara, 7) Usia maksimal 40 tahun, 8) Pembagian fee untuk pengendara : $80 \%$ dari tarif ojek per kilo meter, 9) Tidak menerima jasa kurir dan antar pemesanan makanan atau material lainnya yang menggandung bahan nonhalal.

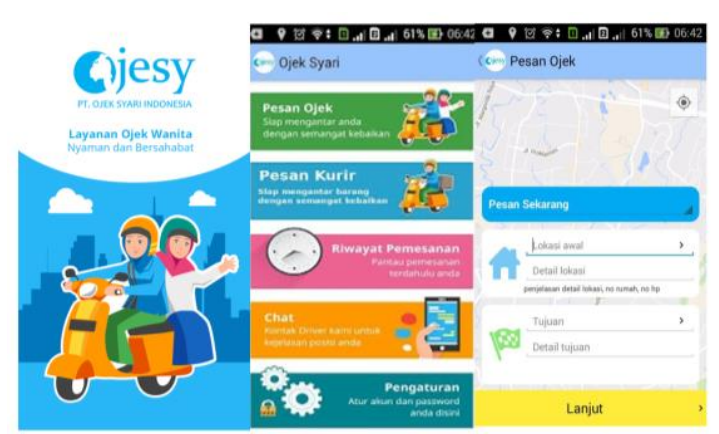

Gambar 1. Tampilan Aplikasi OJESY

Sumber: www.ojeksyari.com (2017)

Ojek telah menjadi layanan antar jemput yang banyak di gunakan oleh masyarakat Indonesia. Ojek dapat digunakan untuk berbagai keperluan penumpang, seperti antar jemput anak ke sekolah sampai mengantar dan menjemput barang atau belanjaan bahkan untuk keperluan perjalanan atau travelling ke suatu tempat untuk rekreasi seperti wisata kuliner, wisata belanja, wisata edukasi atau jenis wisata lainnya dalam lokal wilayan tertentu. Oleh karena itu, perlu dilakukan evaluasi dan penilaian efektifitas dari variabel-variabel pemasaran syariah yang telah dijalankan manajemen ojek syariah untuk dapat meningkatkan jumlah pengguna, memperbesar pemasukan serta turut mengembangkan pariwisata Indonesia

Penelitian ini bertujuan untuk membandingkan pengaruh merek syariah dan religiusitas konsumen terhadap keputusan pelanggan dalam menggunakan OJESY sebagai moda transportasi wisata mereka. Beberapa penelitian sebelumnya telah menemukan bahwa merek syariah memiliki pengaruh penting dalam keputusan pembelian konsumen (Jalil and Rahman, 2014; Fianto et al., 2014). Dalam penelitian ini, merek syariah diukur menggunakan Yusof and Jusoh (2013) dengan penilaian yang terdiri dari nilai (values), atribut (attributes), manfaat (benefits) dan personalitas (personality). Selain itu, peneliti lainnya juga menemukan bahwa religiusitas memainkan peran yang kuat dalam mempengaruhi keputusan konsumen dalam pembelian produk (Haque et al, 2011a; Haque et al, 2011b). Religiusitas diukur menggunakan hasil penelitian Shaari and Arifin (2010); Ahmad et al (2012) dimana akan dinilai pengetahuan konsumen mengenai halal (allowed), haram (forbidden), masbuh (doubtful) dan makruh (disapproved).

Orisinalitas yang ditawarkan dalam penelitian ini adalah belum ditemukannya penelitian mengenai jasa ojek syariah baik di dalam maupun luar negeri khususnya dalam perspektif pemasaran syariah. Oleh karena itu, penelitian ini diharapkan dapat mengisi kekosongan gap. Selain itu, orisinalitas kedua penelitian ini adalah belum ditemukannya penelitian mengenai peran ojek syariah dalam meningkatkan pariwisata di Indonesia.

Penelitian ini dilaksanakan di Kota Malang sebagai salah satu dari 25 kota di Indonesia yang menjadi wilayah operasional OJESY. Peneliti berharap penelitian ini merupakan inisiasi dan kedepannya dapat dikembangkan dalam skala yang lebih luas dalam rangka mengevaluasi kinerja pemasaran syariah dari ojek syariah, memperkuat dan menstimulus penerapan moda transportasi halal lainnya serta meningkatkan perannya dalam mendukung pariwisata di Indonesia.

\section{KAJIAN PUSTAKA Merek Syariah (Sharia Brand)}

Merek produk juga memiliki pengaruh positif pada kepercayaan konsumen dalam membeli dan mengkonsumsi makanan berlabel halal karena menunjukkan "kehalalan" dari produk makanan (Golnaz, Zainal, \& Mad-Nasir, 2012). Hal ini diyakini bahwa skenario ini terjadi karena alasan bahwa sebagian besar umat Islam saat ini sangat berhati-hati tentang apa, kapan, di mana, bagaimana, dari siapa dan berapa banyak untuk mengkonsumsi. 
Dalam hubungannya dengan situasi di atas, peningkatan permintaan produk halal dan intensitas persaingan dalam kekuatan baru dari pasar halal telah menyebabkan munculnya merek syariah. Kekhawatiran ini juga menyebabkan kategorisasi merek syariah lebih rinci dan spesifik. Alserhan (2010) menjelaskan merek adalah sesuai syariah ketika (1) murni merek Islam; produk halal, diproduksi di negara Islam dan ditargetkan pada pasar Muslim, (2) merek islam tradisional; produk diasumsikan halal, berasal dari negara-negara Islam dan ditargetkan pada pasar Muslim, (3) merek Islam dari dalam; produk halal, berasal dari negara-negara Islam dan tidak harus ditargetkan untuk muslim, (4) merek Islam dari luar; produk halal, berasal dari negara-negara non-Islam dan tidak selalu ditargetkan untuk umat Muslim. Hasil kategorisasi ini menunjukkan sikap yang berbeda, norma subjektif, niat dan perilaku pembelian (Alserhan, 2010). Penelitian Yusof and Jusoh (2013) menyatakan bahwa Islamic branding atau merek syariah harus merupakan merek produk yang telah memenuhi nilai, atribut, personalitas sesuai nilai-nilai Syariah. Tabel 1 menampilkan indikator dan item merek syariah berdasarkan penelitian Yusof and Jusoh (2013).

Tabel 1. Referensi Indikator dan Item Merek Syariah

\begin{tabular}{|l|l|}
\hline \multicolumn{1}{|c|}{ Indikator } & \multicolumn{1}{|c|}{ Item } \\
\hline Nilai (Values) & Merek halal adalah elemen penting \\
\hline Atribut (Attributes) & $\begin{array}{l}\text { Membeli produk halal berdasarkan } \\
\text { merek; Elemen Islam secara fisik dan } \\
\text { emosional mengikat pelanggan }\end{array}$ \\
\hline Manfaat (Benefits) & $\begin{array}{l}\text { Merek syariah memberi keyakinan dalam } \\
\text { mengkonsumsi produk; Merek syariah } \\
\text { sudah cukup untuk menunjukkan } \\
\text { "kehalalan" dari produk }\end{array}$ \\
\hline $\begin{array}{l}\text { Personalitas } \\
\text { (Personality) }\end{array}$ & $\begin{array}{l}\text { Membeli produk bermerek halal walau } \\
\text { tidak akrab dengan merek }\end{array}$ \\
\hline
\end{tabular}

Sumber: Yusof and Jusoh (2013)

\section{Religiusitas (Religiosity)}

Studi dalam literatur pemasaran berpendapat bahwa agama sering merupakan kunci unsur budaya, sangat mempengaruhi perilaku, yang pada akhirnya akan mempengaruhi keputusan pembelian. Religiusitas adalah penghayatan agama seseorang yang menyangkut simbol, keyakinan, nilai dan perilaku yang didorong oleh kekuatan spiritual. Sedangkan, religiusitas oleh Mc Daniel dan Burnett (dalam Vittel, 2009) didefinisikan sebagai kepercayaan kepada Tuhan disertai dengan komitmen untuk mengikuti prinsip-prinsip yang diyakini ditetapkan oleh Tuhan. Tabel 2 menampilkan indikator dan item religiusitas yang diukur menggunakan model Religious Belief dari Shaari and Arifin (2009) yang dikembangkan Ahmad et al (2012).

\section{Tabel 2. Referensi Indikator dan Item \\ Religiusitas}

\begin{tabular}{|l|l|}
\hline \multicolumn{1}{|c|}{ Indikator } & \multicolumn{1}{c|}{ Item } \\
\hline Halal (allowed) & $\begin{array}{l}\text { Setiap produk yang dibeli seharusnya halal } \\
\text { Informasi yang memadai tentang kehalalan } \\
\text { produk penting } \\
\text { Menyadari bahwa segala sesuatu yg dikonsumsi } \\
\text { akan mempengaruhi kehidupan }\end{array}$ \\
\hline Haram (forbidden) & $\begin{array}{l}\text { Tahu setiap produk yang Haram bagi Muslim } \\
\text { Tidak mengkonsumsi produk mengandung bahan } \\
\text { non-halal }\end{array}$ \\
\hline Masbuh (doubtful) & $\begin{array}{l}\text { Tahu bahwa produk yang Masbuh perlu dihindari; } \\
\text { Tidak akan membeli jika tidak yakin dengan } \\
\text { kandungan produk }\end{array}$ \\
\hline Makruh (disapproved) & $\begin{array}{l}\text { Tahu ada produk tertentu yang dianggap sebagai } \\
\text { Makruh; } \\
\text { Islam tidak menganjurkan mengkonsumsi } \\
\text { Makruh; }\end{array}$ \\
\hline
\end{tabular}

Sumber: Shaari and Arifin (2009); Ahmad et al (2012).

\section{Keputusan Menggunakan Jasa Syariah}

Menurut Kotler (2000), keputusan pembelian adalah suatu proses penyelesaian masalah yang terdiri dari menganalisa atau pengenalan kebutuhan dan keinginan, pencarian informasi, penilaian sumber-sumber seleksi terhadap alternatif pembelian, keputusan pembelian, dan perilaku setelah pembelian.

Keputusan pembelian merupakan suatu proses pengambilan keputusan akan pembelian yang mencakup penentuan apa yang akan dibeli atau tidak melakukan pembelian dan keputusan itu diperoleh dari kegiatan-kegiatan sebelumnya (Assauri, 2004). Jadi, keputusan pembelian adalah suatu keputusan seseorang dimana dia memilih salah satu dari beberapa alternatif pilihan yang ada. Tabel 3 menampilkan indikator dan item keputusan pembelian yaitu keputusan menggunakan jasa Syariah yang digunakan dalam penelitian ini berdasarkan model Decision Buying dari Kotler and Armstrong (2001).

Tabel 3. Referensi Indikator dan Item Keputusan Jasa Syariah

\begin{tabular}{|l|l|}
\hline \multicolumn{1}{|c|}{ Indikator } & \multicolumn{1}{|c|}{ Item } \\
\hline $\begin{array}{l}\text { Keputusan produk } \\
\text { Product choice })\end{array}$ & $\begin{array}{l}\text { Manfaat utama produk; kualitas; } \\
\text { jaminan; tampilan; fitur; variasi } \\
\text { produk }\end{array}$ \\
\hline $\begin{array}{l}\text { Keputusan merek } \\
\text { (Brand } \text { choice })\end{array}$ & $\begin{array}{l}\text { Merek bereputasi; merek terkenal; } \\
\text { atribut merek }\end{array}$ \\
\hline $\begin{array}{l}\text { Keputusan dealer } \\
\text { (Dealer choice })\end{array}$ & $\begin{array}{l}\text { Lokasi; harga; persediaan; } \\
\text { kemudahan mendapatkan; fasilitas; } \\
\text { infomasi dan promosi }\end{array}$ \\
\hline $\begin{array}{l}\text { Keputusan waktu } \\
\text { (Purchase timing) }\end{array}$ & $\begin{array}{l}\text { Pembelian rutin dan pembelian } \\
\text { berulang }\end{array}$ \\
\hline
\end{tabular}


Keputusan jumlah $\quad$ Jumlah besar; memberikan

(Purchase amount) rekomendasi; jumlah frekuensi pembelian

Sumber: Kotler and Armstrong (2001)

\section{Hubungan Antar Variabel dan Hipotesis Penelitian}

Jalil and Rahman (2014) melakukan penelitian mengenai pengaruh merek Islami terhadap keputusan nasabah dalam menggunakan jasa bank syariah di Kuala Lumpur, Malaysia. Hasil penelitian tersebut menunjukkan bahwa merek Islami yang ditawarkan bank syariah berpengaruh signifikan dan positif terhadap keputusan menabung nasabah bank syariah. Hal ini berarti bahwa semakin kuat merek Islami yang ditawarkan bank syariah maka akan semakin tinggi mempengaruhi keputusan nasabah bank syariah untuk menggunakan jasa bank syariah.

Selain itu, berdasarkan data yang dikumpulkan dari 386 mahasiswa di 13 sekolah Islam di Indonesia, Fianto et al (2014) menemukan bahwa merek yang memiliki citra baik akan mempengaruhi keputusan pembelian konsumen. Oleh karena itu terdapat dasar empiris yang kuat untuk membuktikan pengaruh merek syariah terhadap keputusan menggunakan jasa syariah dalam penelitian ini. Oleh karena itu, gambar 2 menunjukkan hipotesis pertama penelitian ini sebagai berikut:
H1: Merek syariah berpengaruh signifikan terhadap keputusan menggunakan jasa ojek Syariah OJESY di Kota Malang

Haque et al (2011a) melakukan penelitian mengenai pengaruh religiusitas terhadap keputusan konsumen dalam melakukan pembelian produk dari luar negeri. Data dari 450 konsumen Muslim di Malaysia. Hasil analisis menunjukkan bahwa faktor religiusitas dan etnosentris berpengaruh terhadap keputusan konsumen dalam membeli produk dari luar negeri.

Selanjutnya, dengan menggunakan demografi responden dengan usia Muslim muda Haque et al (2011b) melakukan penelitian mengenai pengaruh citra perusahaan, religiusitas dan etnosentrisme terhadap keputusan konsumen untuk membeli produk dari luar negeri. Dengan menggunakan 250 orang konsumen Muslim muda di Malaysia sebagai responden penelitian, penelitian tersebut menunjukkan hasil yang sama dimana faktor religiusitas berpengaruh signifikan terhadap keputusan konsumen dalam membeli produk dari luar negeri. Hasil penelitian tersebut menunjukkan bahwa bagi konsumen Muslim diberbagai usia, hal-hal terkait religiusitas tetap menjadi pertimbangan utama dalam mempengaruhi keputusan pembelian konsumen khususnya pembelian produk negara asing. Oleh karena itu, gambar 2 menunjukkan hipotesis kedua penelitian ini sebagai berikut:

H2: Religiusias Muslim berpengaruh signifikan terhadap keputusan menggunakan jasa ojek syariah OJESY di Kota Malang

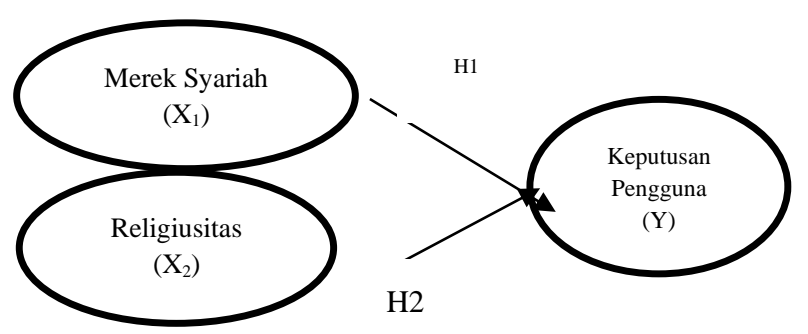

Gambar 2. Model Hipotesis Penelitian

Keterangan:

$\begin{array}{ll}\mathrm{X}_{1} & : \text { Merek Syariah } \\ \mathrm{X}_{2} & : \text { Religiusitas } \\ \mathrm{Y} & : \text { Keputusan Menggunakan Jasa Ojek } \\ \text { Syariah } & \end{array}$

\section{METODOLOGI PENELITIAN}

Metode penelitian yang digunakan dalam penelitian ini adalah penelitian penjelasan (explanatory research) dengan pendekatan kuantitatif. Lokasi yang direncakanan dalam penelitian ini adalah Kota Malang, Provinsi Jawa Timur, Indonesia. Populasi pada penelitian ini adalah keseluruhan wisatawan pengguna ojek syariah OJESY sebagai moda transportasi wisata lokal (staycation). Dikarenakan jumlah populasi tidak diketahui maka penelitian ini menentukan jumlah sampel dengan menggunakan rumus Machin dan Champbell. Berdasarkan penjelasan tersebut, maka jumlah sampel dalam penelitian ini adalah sebanyak 115,02 orang dan dibulatkan menjadi 116 orang wisatawan pengguna OJESY untuk keperluan wisata lokal di Kota Malang.

Metode sampling pada penelitian ini dilakukan dengan pendekatan purposive sampling. Kriteria sampel yang ditetapkan adalah 1) Wisatawan adalah wanita Muslimah dari dalam maupun dari luar Kota Malang 2) Wisatawan 
telah menggunakan jasa OJESY sebagai moda transportasi wisata lokal di Kota Malang. 3) Wisata lokal (staycation) dalam hal ini termasuk wisata kuliner, wisata edukasi, wisata rekreasi, wisata belanja dan lain sebagainya. Penelitian ini menggunakan metode pengumpulan data dengan metode survei dengan menggunakan kuesioner. Variabel independen penelitian ini terdiri dari merek syariah (X1) dan religiusitas (X2) sedangkan variabel dependen penelitian ini adalah keputusan pengguna jasa (Y).

Penelitian ini melakukan analisis data secara kuantitatif yang meliputi 1) Statistik deskriptif berupa penyajian tabel distribusi frekuensi dari tiap-tiap item pertanyaan yang didukung pula dengan penggunaan diagram; 2) Statistik inferensial untuk menguji hipotesis penelitian menggunakan analisis path dengan alat analisis data Statistical Package for the Social Sciences (SPSS). Teknik analisis statistik dalam penelitian ini digunakan untuk menguji hipotesis penelitian dengan menggunakan regresi berganda (multiple regression). Uji kuesioner telah dilakukan melalui uji validitas dan realiabilitas pada 30 orang responden dengan hasil valid dan reliabel sehingga dapat digunakan pada tahap lebih lanjut dalam penelitian ini.

\section{HASIL DAN PEMBAHASAN \\ Hasil Analisis Statistik Deskriptif}

Mayoritas karakteristik responden yang didapatkan dalam penelitian ini terdiri dari "Destinasi Tujuan Wisata", "Usia”, "Asal”, serta "Pendapatan per bulan". Responden yang berasal dari luar kota Malang sebanyak 81 orang atau sebesar $69,8 \%$ dari total keseluruhan responden. Selain itu, 44 orang atau $37,9 \%$ dari total responden merupakan wisatawan yang mengunjungi destinasi wisata belanja di kota Malang dan 51 orang atau 43,9\% dari total responden merupakan wisatawan kuliner. 70 orang atau sebesar $60 \%$ dari total keseluruhan responden memiliki pendapatan tiap bulan dibawah Rp 1.000.000.

Berdasarkan penjelasan yang terdapat pada tabel 4, dapat diketahui bahwa dari total keseluruhan responden adalah 116 orang. Responden yang berasal dari luar kota Malang sebanyak 35 orang atau sebesar 30,2\% dari total keseluruhan responden. Responden yang berasal dari luar kota Malang sebanyak 81 orang atau sebesar 69,8\% dari total keseluruhan responden.
Tabel 4. Distribusi Responden Berdasarkan Asal Responden

\begin{tabular}{|c|c|c|}
\hline Asal & $\begin{array}{c}\text { Jumlah } \\
\text { Responden }\end{array}$ & $\begin{array}{c}\text { Persentase } \\
(\%)\end{array}$ \\
\hline $\begin{array}{c}\text { Luar Kota } \\
\text { Malang }\end{array}$ & 35 & 30,2 \\
\hline $\begin{array}{c}\text { Dalam Kota } \\
\text { Malang }\end{array}$ & 81 & 69,8 \\
\hline Total & 116 & 100 \\
\hline
\end{tabular}

Tabel 5 menunjukkan bahwa dari total 116 orang responden, 78 orang atau sebesar 67,2 $\%$ dari total keseluruhan responden berusia antara 17 sampai dengan 21 tahun, 37 orang atau sebesar $31,9 \%$ dari total keseluruhan responden berusia antara 22 sampai dengan 26 tahun, 1 orang atau sebesar $0,9 \%$ dari total keseluruhan responden berusia antara 27 sampai dengan 31 tahun.

Tabel 5. Distribusi Responden Berdasarkan Usia

\begin{tabular}{|c|c|c|}
\hline Usia (Tahun) & $\begin{array}{c}\text { Jumlah } \\
\text { Responden }\end{array}$ & Persentase (\%) \\
\hline $17-21$ & 78 & 67,2 \\
\hline $22-26$ & 37 & 31,9 \\
\hline $27-31$ & 1 & 0,9 \\
\hline Total & 116 & 100 \\
\hline
\end{tabular}

Tabel 6 menunjukan bahwa dari total 116 responden, 44 orang atau $37,9 \%$ dari total responden merupakan wisatawan yang mengunjungi destinasi wisata belanja di kota Malang, 1 orang atau $0,86 \%$ merupakan wisatawan wisata religi, 51 orang atau 43,9\% dari total responden merupakan wisatawan kuliner. Kemudian, 8 orang atau 6,89\% responden merupakan wisatawan pada destinasi wisata kesehatan dan 12 orang atau 10,3\% responden merupakan wisatawan pada destinasi rekreasi.

Tabel 6. Distribusi Responden Berdasarkan Jenis Destinasi Wisata

\begin{tabular}{|c|c|c|}
\hline Pendidikan & $\begin{array}{c}\text { Jumlah } \\
\text { Responden }\end{array}$ & Persentase (\%) \\
\hline Wisata Belanja & 44 & 37,9 \\
\hline Wisata Edukasi & - & - \\
\hline Wisata Religi & 1 & 0,86 \\
\hline Wisata Kuliner & 51 & 43,9 \\
\hline Wisata Kesehatan & 8 & 6,89 \\
\hline Wisata Rekreasi & 12 & 10,3 \\
\hline Lainnya & - & - \\
\hline Total & 116 & 100 \\
\hline
\end{tabular}

Tabel 7 menjelaskan bahwa dari keseluruhan 116 responden, 70 orang atau sebesar $60 \%$ dari total keseluruhan responden memiliki pendapatan tiap bulan dibawah Rp 1.000.000, 21 orang atau sebesar $19 \%$ dari total keseluruhan 
responden memiliki pendapatan tiap bulan sebesar Rp 1.000.000 sampai dengan kurang dari Rp 1.500.000, 11 orang atau sebesar $9 \%$ dari keseluruhan responden memiliki pendapatan tiap bulan sebesar Rp 1.500.000 sampai dengan kurang dari Rp 2.000.000, 14 orang atau sebesar $12 \%$ dari total keseluruhan responden memiliki pendapatan tiap bulan diatas $\mathrm{Rp} 2.000 .000$. Tingginya penggunakan ojek pada mayoritas responden dengan pendapatan kateogori rendah diyakini karena harga yang ditawarkan layanan ojek tepat dengan kondisi keuangan responden. Hal ini juga sesuai dengan target utama OJESY yaitu ibu rumah tangga dan remaja. Harga motor yang semakin murah dan kredit yang mudah didapatkan memungkinkan responden dengan kategori pendapatan lebih tinggi cenderung menggunakan transportasi pribadi dibandingkan dengan kendaraan umum.

Tabel 7. Distribusi Responden Berdasarkan Pendapatan Tiap Bulan

\begin{tabular}{|c|c|c|}
\hline Pendapatan (Rupiah) & $\begin{array}{c}\text { Jumlah } \\
\text { Responden }\end{array}$ & Persentase (\%) \\
\hline$<1.000 .000$ & 70 & 60 \\
\hline $\begin{array}{c}1.000 .000< \\
1.500 .000\end{array}$ & 21 & 19 \\
\hline $\begin{array}{c}1.500 .000< \\
2.000 .000\end{array}$ & 11 & 9 \\
\hline $2.000 .000>$ & 14 & 12 \\
\hline Total & 116 & 100 \\
\hline
\end{tabular}

\section{Hasil Analisis Statistik Inferensial}

Tabel 8 menampilkan hasil analisis regresi berganda dalam penelitian ini. Berdasarkan tabel tersebut, diketahui pengaruh secara parsial dari variabel merek syariah dengan melihat nilai t-hitung $>\mathrm{t}$-tabel $(5,704>5,731)$ dan nilai koefisien beta 0,564 atau dianggap signifikan, maka terdapat pengaruh signifikan dari merek syariah OJESY terhadap keputusan menggunakan jasa ojek syariah. Selain itu, diketahui pengaruh secara parsial dari variabel religiusitas dengan melihat nilai t-hitung $>\mathrm{t}$-tabel $(5,926>5,731)$ dan nilai koefisien beta 0,590 atau dianggap signifikan, maka terdapat pengaruh signifikan atas faktor religiusitas Muslim terhadap keputusan menggunakan jasa ojek syariah.

\section{Tabel 8. Hasil Analisis Regresi Berganda}

\begin{tabular}{|c|c|c|c|c|l|}
\hline $\begin{array}{c}\text { Hipotesi } \\
\mathrm{s}\end{array}$ & $\begin{array}{c}\text { Independe } \\
\mathrm{n}\end{array}$ & $\begin{array}{c}\text { Depend } \\
\text { en }\end{array}$ & $\begin{array}{c}\text { Koefisien } \\
\text { beta }\end{array}$ & $\mathrm{p}$-value & Keterangan \\
\hline $\mathrm{H} 1$ & $\mathrm{X} 1$ & $\mathrm{Y}$ & 0,564 & 0,000 & Signifikan \\
\hline $\mathrm{H} 2$ & $\mathrm{X} 2$ & $\mathrm{Y}$ & 0,590 & 0,000 & Signifikan \\
\hline
\end{tabular}

Tabel 9 menampilkan arah hubungan antar variabel yang diukur menggunakan indikator koefisien jalur. Koefisien jalur untuk pengaruh dari masing-masing variabel terlihat pada kolom koefisien jalur dari hasil perhitungan analisis regresi berganda dengan menggunakan SPSS. Pengaruh Merek Syariah (X1) terhadap Keputusan Pembelian memiliki koefisien jalur yang bertanda positif dengan nilai sebesar 0,564. Sedangkan untuk pengaruh Religiusitas (X2) terhadap Keputusan Pengguna Jasa (Y) memiliki koefisien jalur yang bertanda positif dengan nilai sebesar 5,190.

\section{Tabel 9. Hubungan Antar Variabel}

\begin{tabular}{|c|c|c|c|}
\hline Independen & Dependen & $\begin{array}{c}\text { Koefisien } \\
\text { jalur }\end{array}$ & Keterangan \\
\hline $\mathrm{X} 1$ & $\mathrm{Y}$ & 0,564 & Positif \\
\hline $\mathrm{X} 2$ & $\mathrm{Y}$ & 5,190 & Positif \\
\hline
\end{tabular}

Untuk menguji apakah variabel bebas secara parsial berpengaruh signifikan terhadap variabel terikat maka digunakan $p$-value pada signifikasi $\alpha=5 \%$. Berikut adalah tabel 7 yang menunjukkan hasil uji hipotesis menggunakan indikator $p$-value, apabila $p$-value $<0,05=\mathrm{H}_{0}$ ditolak dan $p$-value $>0,05=\mathrm{H} 0$ diterima.

Tabel 10. Hasil Pengujian Hipotesis

\begin{tabular}{|c|c|c|c|c|c|}
\hline Independen & Dependen & Beta & $\mathrm{t}$ & $\mathrm{Sig} \mathrm{t}$ & Keterangan \\
\hline & & & & & \\
$\mathrm{X} 1$ & & 0,564 & 5,704 & 0,000 & Signifikan \\
\cline { 1 - 3 } $\mathrm{X}_{2}$ & $\mathrm{Y}$ & 0,590 & 5,926 & 0,000 & Signifikan \\
\hline
\end{tabular}

Dari hasil $p$-value yang ditunjukkan tabel 10 menunjukkan bahwa kedua hipotesis yang diajukan diterima.

1. Nilai signifikansi p-value sebesar $0,000<$ $0,05=\mathrm{H} 0$ ditolak dan $\mathrm{H} 1$ diterima. Berarti merek syariah OJESY memiliki pengaruh signifikan tehadap keputusan pengguna jasa ojek syariah. Hal ini disebabkan konsumen Muslim mulai selektif dalam memilih moda transportasi yang memenuhi nilai-nilai syariah.

2. Nilai signifikansi p-value sebesar $0,000<$ $0,05=\mathrm{H}_{0}$ ditolak dan $\mathrm{H} 2$ diterima. Berarti religiusitas Muslim memiliki pengaruh yang signifikan terhadap keputusan pengguna jasa 
ojek syariah. Hal ini disebabkan karena religiusitas terbukti memiliki pengaruh yang kuat dalam berbagai perilaku konsumen Muslim, tidak terkecuali keputusan menggunakan jasa moda transportasi yang memenuhi nilai-nilai syariah.

PEMBAHASAN

\section{Merek Syariah terhadap Keputusan Menggunakan Jasa Ojek Syariah}

Penelitian ini menunjukkan bahwa merek syariah berpengaruh signifikan terhadap keputusan wisatawan muslimah menggunakan layanan ojek syari OJESY. Arah hubungan positif menunjukkan bahwa semakin baik merek syariah yang dipositioningkan di benak konsumen yaitu dalam hal ini wisatawan Muslimah maka akan semakin meningkatkan keputusan konsumen untuk menggunakan layanan OJESY.

Hasil penelitian ini mendukung hasil penelitian Jalil and Rahman (2014) melakukan penelitian mengenai pengaruh merek Islami terhadap keputusan nasabah dalam menggunakan jasa bank syariah. Hasil penelitian tersebut menunjukkan bahwa merek Islami yang ditawarkan bank syariah berpengaruh signifikan dan positif terhadap keputusan menabung nasabah bank syariah. Hal ini berarti bahwa semakin kuat merek Islami yang ditawarkan bank syariah maka akan semakin tinggi mempengaruhi keputusan nasabah bank syariah untuk menggunakan jasa bank syariah. Selain itu, penelitian ini juga mendukung hasil penelitian Fianto et al (2014) yang menemukan bahwa merek yang memiliki citra baik akan mempengaruhi keputusan pembelian konsumen. Oleh karena itu, pengaruh merek syariah terhadap keputusan menggunakan jasa syariah dalam penelitian ini sejalan dengan hasil penelitian Jalil and Rahman (2014) serta Fianto et al (2014).

Dapat disampaikan bahwa Merek Syariah yang terdiri dari nilai, atribut, manfaat dan personalitas syariah yang melekat pada merek OJESY mampu mendorong keputusan menggunakan jasa syariah dari wisatawan Muslimah yang terdiri dari keputusan produk, keputusan merek, keputusan dealer, keputusan waktu dan keputusan jumlah.

Peneliti menyimpulkan bahwa wisatawan Muslim yang menggunakan OJESY untuk mengunjungi destinasi wisata di Kota Malang telah menyadari bahwa merek syari yang ditampilkan OJESY pada logo dan tampilan apliasi mereka serta atribut rider mereka merupakan elemen penting yang menarik wisatawan Muslimah, mempertimbangkan menggunakan jasa ojek yang mengusung merek syari, elemen Islam seperti atribut pakaian, logo dan slogan yang ditampilkan OJESY memikat pelanggan secara emosional, merek syariah yang ditawarkan OJESY memberikan keyakinan dalam menggunakan jasa ojek syariah karena tidak menggunakan jasa rider laki-laki sehingga lebih nyaman digunakan untuk wanita, anak-anak dan khususnya Muslimah, merek syariah yang di tonjolkan OJESY secara serta merta meyakinkan pengguna bahwa dalam operasional OJESY telah menggunakan nilai-nilai syariah, pengguna layanan OJESY memilih menggunakan layanan ojek syari karena merek halal yang ditampilkan walau belum mengenal sistem operasional ojek syari sebelumnya.

\section{Religiusias terhadap Keputusan Menggunakan Jasa Ojek Syariah}

Hasil penelitian ini menunjukkan bahwa, religiusitas berpengaruh signifikan terhadap keputusan wisatawan muslimah menggunakan layanan ojek syari OJESY. Arah hubungan positif menunjukkan bahwa semakin tinggi tingkat religiusitas wisatawan Muslimah maka akan semakin mendorong keputusan mereka menggunakan layanan OJESY.

Haque et al (2011a) melakukan penelitian mengenai pengaruh religiusitas terhadap keputusan konsumen dalam melakukan pembelian produk dari luar negeri. Hasil analisis menunjukkan bahwa faktor religiusitas dan etnosentris berpengaruh terhadap keputusan konsumen dalam membeli produk dari luar negeri. Selanjutnya, dengan menggunakan demografi responden dengan usia Muslim muda Haque et al (2011b) melakukan penelitian mengenai pengaruh citra perusahaan, religiusitas dan etnosentrisme terhadap keputusan konsumen untuk membeli produk dari luar negeri. Hasil penelitian tersebut menunjukkan bahwa bagi konsumen Muslim diberbagai usia, hal-hal terkait religiusitas tetap menjadi pertimbangan utama dalam mempengaruhi keputusan pembelian konsumen khususnya pembelian produk negara asing. Oleh karena itu penelitian ini sejalan dengan hasil penelitian Haque et al (2011a) dan Haque et al (2011b) dimana penelitian ini menunjukkan terdapat pengaruh religiusitas terhadap keputusan penggunaan jasa ojek syariah dalam penelitian ini. 
Dapat disampaikan bahwa religiusitas yang dimiliki wisatawan Muslimah yang terdiri dari pengetahuan halal, haram, makruh dan masbuh yang melekat wisatawan Muslimah mampu mendorong keputusan menggunakan jasa ojek syari dari wisatawan Muslimah yang terdiri dari keputusan produk, keputusan merek, keputusan dealer, keputusan waktu dan keputusan jumlah.

Peneliti menyimpulkan bahwa wisatawan Muslim yang menggunakan OJESY untuk mengunjungi destinasi wisata di Kota Malang telah menyadari bahwa setiap produk yang digunakan Muslim seharusnya hanya produk yang terjamin kehalalannya, setiap menggunakan produk melihat informasi yang memadai mengenai kehalalan produk, menyadari bahwa segala sesuatu yang dikonsumsi akan mempengaruhi kehidupan Muslim, Muslim perlu mengetahui produk produk yang haram untuk dikonsumsi, tidak menggunakan layanan yang tidak sesuai nilai syariah, mengetahui bahwa produk yang masbuh perlu dihindari, tidak akan menggunakan layanan produk jika tidak yakin dengan kandungan produk, mengetahui ada produk tertentu yang dianggap makruh dan mengetahui Islam tidak mengajurkan menggunakan layanan produk yang makruh, tidak terkecuali pada keputusan menggunakan jasa layanan ojek.

\section{KESIMPULAN DAN SARAN Kesimpulan}

Meskipun keduanya memiliki pengaruh signifikan dan positif, religiusitas memainkan peran yang lebih besar dibandingkan merek syariah dalam mempengaruhi keputusan menggunakan jasa ojek syariah sehingga spiritual driven menjadi pendorong utama. Pengguna jasa ojek syariah menjaga nilai-nilai syariah dalam menggunakan jasa moda transportasi publik, terlepas dari stimulus perusahaan dalam hal penggunakan merek dengan label merek syariah, jelas dorongan utama pengguna jasa adalah stimulus internal yaitu religiusitas diri.

\section{Saran}

\section{Saran Teoretis}

Kedepannya dapat dilakukan penelitian kuantitatif mengenai Mobile Apps Service Quality (Wulfret, 2019) atau Service Quality in Public Transport (Friman et al, 2020) menggunakan perpektif pengguna moda transportasi ojek khususnya ojek syariah.

\section{Saran Praktis}

1. Perusahaan OJESY sebaiknya meningkatkan positioning merek syariah yang telah ditawarkan dengan mengikuti kegiatan sponsorhip, event, edukasi safety-rider dan syari-rider dan kegiatan lainnya sehingga merek syariah yang telah ada dapat lebih melekat dibenak konsumen dan memperkuat posisinya sebagai penyedia jasa layanan ojek online pertama dan satu-satunya di Indonesia yang berbasis nilai-nilai Islam.

2. Perusahaan OJESY sebaiknya kedepannya melakukan pendaftaran sertifikasi syariah untuk operasionalnya dari Dewan Syariah Nasional- Majelis Ulama Indonesia (DSNMUI) karena meskipun belum ada fatwa khusus mengenai moda transportasi syariah dari MUI tapi dengan mengklaim merek syariah maka sewajarnya OJESY telah lulus dan mengantongi sertifikasi syariah dari MUI sehingga lebih mampu menstimulus religiusitas pengguna dan memperkuat merek syariah dari OJESY

\section{DAFTAR PUSTAKA}

Ahmad, Khaizie Sazimah, Nurul Hidayah Mat Nor, Sharina Shariff, Nurul Zamratul Asyikin Ahmad (2012) Determinants Of Purchase Intention Towards Halal Products Between Rural And Urban Muslim Consumers In Malacca, International Conference On Islamic Economy And Business

Akyol, M. and Kilinc, O. (2014), "Internet and Halal Tourism Marketing", Electronic Turkish Studies. 9(8), 171-186

Alserhan, B.A. (2010). Islamic branding: A conceptualization. Journal of Brand Management, 18(1), 34-49.

Assauri, Sofjan. (2004). Manajemen Pemasaran. Jakarta: Rajawali PressDin, K.H. (1982) Tourism in Malaysia - competing needs in a plural society, Annals of Tourism Research, 9, 453-480

Duman, T. (2011), Value of Islamic Tourism Offering: Perspectives from the Turkish Experience. Paper presented at World Islamic Tourism Forum (WITF 2011), Malaysia

Fianto, Achmad., Yanu Alif., Djumilah Hadiwidjojo., Siti Aisjah and Solimun (2014) The Influence of Brand Image on 
Purchase Behaviour Through Brand Trust. Business Management and Strategy, 5 (2), 58-76

Friman, M., Lättman K., Olsson L.E. (2020) Public transport quality, safety, and perceived Sustainability, 12 (9), 3563

Garrison W.L and Levinson, D.M (2006) The Transportation Experience: Policy, Planning, and Deployment, Oxford University Press, New York.

Golnaz, R., Zainal, A.M. \& Mad-Nasir, S. (2012), Assessment of Consumers' Confidence on Halal Labelled Manufactured Food in Malaysia, Social, Science. \& Humanities. 20 (1), 33-42.

Haque A, Rahman S, Ahmed IS (2011a). Factors influencing purchase of foreign goods by Malay Muslim consumers: a structural equation modelling approach on religiosity and ethnocentrism perspectives. The Social Sciences 6(5):420-428.

Haque, Ahasanul, Sabbir Rahman and Farzana Yasmin (2011b) Exploring the Relationship between Religiosity, Ethnocentrism and Corporate Image: Young Muslim Consumers Perspective, Journal of Business and Policy Research, 7(1). Special Issue. Pp. 60 - 71

Jalil, D.M.A. and Rahman, M.K. (2010), "Financial transactions in islamic banking are viable alternatives to the conventional banking transactions", International Journal of Business and Social Science , 1 (3), pp. 219-233.

Kotler, Philip and Gary Armstrong. (2001). Prinsip-Prinsip Pemasaran. Jilid 1. Erlangga, Jakarta

Kotler, Plilip.(2000). Manajemen Pemasaran. Edisi Mileinium. Jakarta : PT. Indeks Kelompok Gramedia.

Shaari, J. A. N. and Arifin, N. S. (2010) Dimension of Halal Purchase Intention: A Preliminary Study. International Review of Business Research Papers, 6(4), 444-456

Vittel, Scott J,(2009) “The Role of Religiosity in Business and Consumer Ethics: A Review of the Literature" Journal of Business Ethics, 90, pp. 155-167
Wulfert, T. (2019). Mobile App Service Quality Dimensions and Requirements for Mobile Shopping Companion Apps. Junior Management Science, 4(3), 339-391.

Yusof, Y. M., and Jusoh, W. W. (2014). Islamic branding: the understanding and perception. Procedia-Social and Behavioral Sciences, 130, 179-185. 